\title{
Land Conversion in Namlea District
}

\author{
Tim Kerja PSP2M
}

\begin{abstract}
The phenomenon of agricultural land conversion in Namlea subdistrict becomes a problem when the number of productive land is increasingly reduced and affects land availability for agricultural production. Research was conducted to describe the conversion of agricultural land and its utilization in Namlea subdistrict. The research site focuses on Namlea District Buru Regency with consideration of the availability of the number of agricultural land that is less than other districts in Buru Regency. The number of informant interviewed as many as 40 people consisting of land owners, farmers, business owners and village apparatus. Analytical techniques used to follow the concept of Miles and Huberman where activities in the analysis of qualitative data are conducted interactively and continuously to find saturation in data processing. The results showed that the reduction of farmland in Namlea district was due to the conversion of land for various activities including housing and development of the Trade Center. In addition, the use of converted land is caused by the system of personal ownership that is secured by the Government through the right to building or proprietary rights but has not fully set the long-term oriented land utilization pattern.
\end{abstract}

Keywords: Namlea, Conversion, Farmland, Village, Buru

\section{INTRODUCTION}

Namlea subdistrict is the capital of Buru Regency consisting of 11 villages and 9 hamlets. The area of Namlea subdistrict is $226.55 \mathrm{~km}^{2}$ and has the highest number of inhabitants in Buru regency. Inhabitants of Namlea sub-district according to the data of Central Statistic Bureau year 2018 is 34,326 inhabitants. This number has increased steadily every year with a population growth rate of 6.26 percent[1]. With the addition of this population, it automatically resulted in higher levels of population density in Namlea subdistrict. The increase in the density of the population is rapidly resulting in the need for land as a place of activity in Namlea subdistrict also increased[2].

Due to the increase in population and increased per capita consumption stimulated by the increase in household income, food needs such as rice or horticultural food will continue to increase. To compensate for these needs, the production in the region must increase proportionally to adequate in order to maintain food adequacy. But in Namlea subdistrict has occurred slowing the rate of production growth is more due to reduced agricultural land and slowing down the growth rate of farming productivity plus the absence of technological breakthrough that is able to improve Significant food productivity.

In the situation where the district government of Buru regency increasingly difficult to increase production due to increased conversion of agricultural land to non-agricultural[3] then this condition will enlarge the local food problem. Based on this, agricultural land conversion control efforts have an increasingly important role in supporting food security in Namlea subdistrict. Farmland conversion control efforts are also needed to avoid various social, economic and environmental issues as a result of land conversion[4]. Rather than land function or land conversion can be interpreted as a change in the function of land area from its function, to be another function that could cause environmental impact or problems and potential of land, but the effort to control The land conversion was so far overlooked[5], it was demonstrated by the development of agricultural land conversion activity to non-agricultural land, with indications of housing and retail developments up to 15 percent annually.

In the previous studies, Hidayat with analysis of the conversion of farmland that occurred in Kecamatan Kertajati showed that the conversion of agricultural land can cause negative impact of social and economic loss for households Farmer[6], while Riswandi in his research found conversion of farmland occurred as a logical consequence of the development of agricultural land conversion often caused negative impacts especially in the context of food security and Farmers' socio-economic condition[7][8]. Hidayat discovered the economic impact of social impacts on land conversion is the shift and diversification of farmers ' livelihoods in agriculture and non-agriculture. The farmer's household income became increased, fixed and decreased depending on the type of new business involved.

This article aims to obtain a primary description of the impact that occurred due to the increasing conversion of agricultural land to non-agriculture in Namlea subdistrict[9][10], it is important given the magnitude of the role of research results in forming and Influence local policy to restrict the conversion of land to non-farms for the creation of food-security communities.

\section{LITERATURE REVIEW}

\subsection{Over the Land Function}

Farmland has enormous benefits for human survival. The benefit is not only from the economic sector, but also other sectors such as the environment, biological[11]. Therefore, the increasing number of land function that occurs during this time will cause various problems. Lestari defines land function or is often referred to as land conversion is a change in the function of some or all areas of the land from its original function (as planned) into other functions that are negatively impacted (problem) The environment and potential of the land itself[12]. Land transfer can also be interpreted as a change for other uses caused by factors that outline the need to meet the growing needs of the population and the increasing demands of quality A better life[13].

The impact of macro-land function is the availability of food that decreases and results in the reduction of food security nationwide[14]. By micro, the function of the land resulted in farmers who originally sought food crops and could fulfill their 
own food availability (rice) for his household became not having rice and had to buy. Another impact of land function is the loss of its livelihood as a farmer[15].

There are three important factors that cause the function of rice field land is[16]; (1) external factors, is a factor caused by the dynamics of urban growth, demographics and economics. (2) Internal factors, this factor is more see the side caused by domestic socio-economic conditions of land-users farm. (3) Policy factors. That is the regulatory aspect issued by the central and local governments related to the change of agricultural land function. The weakness in the regulatory or regulatory aspects itself is primarily related to legal force issues, violation sanctions, and accuracy of land objects that are prohibited to be converted.

\subsection{Farmland}

Agricultural land is a contributing factor to the life needs of the community, especially rural and suburban communities. Most of the communities in rural and suburban areas are earning or relying on agriculture-moving businesses[17]. However, farmland or rice fields have been converted into industrial land, housing and surface, causing the production of national rice to continue to decline[18].

Empirically the farmland that is most vulnerable to the over function is the rice fields[19]. It is caused by; Population density in rural areas that have dominant agroecosystems in the fields are generally much higher than the dry land agroecosystem, many area of the location is adjacent to urban areas, infrastructure area of paddy Generally better than dry land areas, as well as the construction of infrastructure and settlement facilities, industrial areas, and so on tend to be fast in the flat masked region, where in areas with such topography ecosystem The farm is dominant in paddy fields[20].

There are two types of requests affecting land demand, i.e. direct demand and demand pushers[21]. In direct demand, the land serves as a consumer goods (for settlements) and directly provides utilities. Through derived demand, the increase in population will increase the demand for goods and services as a means of loading needs. To produce such goods and services required land as a production factor. In this case, the land does not provide utilities directly, but the utility is derived from the consumption of goods and services. When the demand for land has increased while its availability is increasingly limited, the community often do is to change land use from one use to another[22]. Land use change is dynamic, and changes are likely to lead to land rent which provides higher land rental.

\subsection{Land Tenure}

Land is an important factor for people whose lives depend on the agricultural sector. Land tenure is not only important for agriculture, but also for the determination of various other needs in community life. The land not only serves as a profutive asset but as a commodity that can be supplied[23]. It shows that land has the role of an asset as well as a commodity that can change hands and the status of its pronunciation at any time. Changes in land tenure will affect the socio-economic condition of farmers, because of loss of rights and ownership of a land[24].

Distribution of agricultural land ownership in a region can be used as an overview of the equality of the production factor by looking at how many people are able to control the Loopgum land and area[25]. Through this, it can also be known that agricultural land as a source of income for peasant households so that it can be used as an indicator of welfare level although it can not fully reflect the level of welfare Actually.

In Indonesia, the status of land ownership is governed by the principal law of agrarian Number 5 year 1960 on agrarian trees. The type of land ownership status is several levels, namely; (1) Property rights are the right, most powerful, and full-fledged individual primer that can be owned without any expiry time, for the ownership of land in a particular area mentioned in the certificate. The. (2) Building rights are the right to establish and possess buildings on land owned by the other party within a maximum period of 30 years and may be extended for 20 years. If this is the time, users of this right can apply for another 30 years of entitlement. The building rights can only be obtained by Indonesian nationals and companies established under Indonesian law and domiciled in Indonesia. (3) Business rights, the rights granted only to the legal entity established under Indonesian law and domiciled in Indonesia to seek the land directly controlled by the state for a certain time[26]. In general, it is the land of the country used as forest of industrial plants, plantations, fisheries, or agriculture.

\section{Method}

The research was conducted in Namlea subdistrict, Buru regency. The determination of the research site was conducted purposive[27] with the consideration that Namlea Sub-district as a research site because it has a percentage of land area that has been converted to greater than other sub-district based on body data Statistical Center. The number of informant interviews of 40 people taken in purposive[28] In consideration of the informant is regarded as the related parties to achieve the research objectives[29]. The informant is the owner of agricultural land, farmers, business owners and village apparatus.

The data on this research is derived from primary data sources and secondary data, with data collection techniques used through observations, interviews, questionnaire and library studies[30]. In the step of the interview the researcher conducted a thorough interview with the informant[31] and made a direct observation of all activities conducted by the informant. Researchers are also looking for complementary information related to land function through discussions with village apparatus regarding the existence of agricultural land-function activities. The interview was conducted at 17.00-22.00 where the researchers adjusted the working time and the rest of each informant.

The analytical techniques used in this study are qualitative data analysis following the proposed concept of Miles and 
Huberman and Spradley[32]. Miles and Huberman, suggests that activities in the analysis of qualitative data are conducted interactively and ongoing continuously at every stage of the research so as to complete and data until saturated. Activity in data analysis i.e. data reduction, data presentation, withdrawal of conclusions.

\section{Result}

\subsection{Condition of Farmland in Namlea Subdistrict}

Land as one of the important resources for the existence of farmers in conducting agricultural activities is increasingly threatened because of the need for the development of housing and industry. The existence of agricultural land in Namlea subdistrict. Extensive land will further enlarge the expectations of farmers to be able to live worthy. Along with the increasing population, the presence of land especially agricultural land is increasingly threatened due to the need for more land. While the number of available soils does not increase.

Table 1 shows that Namlea village is an area that has the largest administrative area with a very small percentage of agricultural land while Lala village with an area administrative of about $8 \mathrm{Km}^{2}$ has a farm land $12 \mathrm{Ha}$ Which is the smallest amount compared to other villages.

Supporting factors in the period of reduced agricultural land is the distance between the village with the central Capital District. The villages of Namlea and Lala are the two closest locations in which the village of Namlea is $0 \mathrm{Km}$ from the Central District and Lala is $3 \mathrm{Km}$ from the town of Namlea.

\subsection{Ownership and Possession of Agricultural Land}

Unregulated ownership and possession of farmland will be the main factor that supports the occurrence of land function. The personal ownership of a land will open up opportunities for the owner in a short time can carry out land function for fulfillment needs. The following are presented farmland ownership in Namlea distric

Table 2 shows the amount of land ownership which continues to decrease from year to year where the largest amount occurs in the village of Namlea with an average reduction of ownership reaching 3-4 Ha per year. This means that the agricultural land was reduced by selling to other parties. In the observation conducted by researchers, most of the farm's land turned into offices and trading centers. Batuboi Village is a region that has reduced ownership of agricultural land, and the results of the field show that 80 percent of the villagers still have a farmer and still retain their farm to Remain processed.

In other studies, utilization of land can be mapped into several parts such as industry, housing, land, office, and open land. The following is presented general land utilization in Namlea subdistrict.

Table 3 shows the utilization of land done by the community in Namlea District with the largest number of housing sectors. Namlea Village as the village is the most large amount of land utilization for 586 hectares, while Siahoni village is a village with the amount of land utilization for the least housing.

In the development of land utilization in Namlea subdistrict as well as increasing the need for infrastructure development and trading centers, the utilization of open land will be reduced, in predictor the development of Namlea subdistrict is still Need approximately 500 hectares of land for the development so that the existence of open land will continue to undergo reductions in subsequent years.

\section{Discussion}

Village and city development planning requires careful calculations in land utilization[33]. In fact the city became irregular due to the arrangement and regulation of uncontrolled land utilization from the first time the construction was conducted.

The area of the agricultural land in Namlea district is quite large, the influence of city center development resulted in areas such as Lala Village[34], Namlea and Karang Jaya targeted community to do over functions such as building shelter and trading center . Reduction of farmland that occurred in several villages due to community needs not as a result of degradation of land quality but rather economical calculation to carry out daily activities related to the fulfillment of household needs.

The ownership of agricultural land in Namlea subdistrict is divided into several parts of which are ownership of lineage[35], ownership derived from the results of business and ownership derived from customs. Of the three factors that most dominate the change of utilization is the result of the business where people prefer to invest in their land[36]. Agricultural land turned into a center of commerce and shops as a result of the needs and trends of communities that need space for economic activities. In addition, land investment is also considered profitable and has convenience in its implementation.

The use of land divided into industrial, residential, agriculture, office and open land become a description of land mapping in Namlea subdistrict. In the utilization, the community dominates land use in housing as a basic need that must be fulfilled in addition to the land that is easier and cheaper to convert is farmland at a price that is still affordable[37]. Land utilization is very related to ownership where ownership is governed by the rights of buildings, property rights, rights of use. Of the three rights 
inherent in land status, building rights are the main choice for the community to invest and convert the land function as a result of protection from the country.

\section{CONCLUSION}

Generally, agricultural land conditions in Namlea subdistrict have the development of utilization where land conversion is more geared towards investments outside the farm. Some of the ways used are selling or renting with motifs to get profit on the land. Land tenure in Namlea subdistrict is generally private land and customary land. The State guarantees such ownership in the form of property rights, building rights and use rights, these three rights open opportunities for investment outside the agricultural sectors. Land utilization is dominated by housing sector due to the addition of residents and the development of the city which causes the need for shelter is increasing.

\section{REFERENCES}

[1] M. C. B. Umanailo, "Integration of Community Empowerment Models [Pengintegrasian Model Pemberdayaan Masyarakat]," Proceeding Community Dev., vol. 2, p. 268, Mar. 2019.

[2] M. C. B. Umanailo, "Discourse on the Consumerist Community Consumption," J. Soc. Sci. Res., vol. 5, no. 54, pp. 1181-1186, Apr. 2019.

[3] M. C. B. Umanailo, "Studi pada Masyarakat Desa Waimangit Kabupaten Buru," SOCA, vol. 12, no. 12, pp. 63-74, 2018.

[4] M. C. B. Umanailo, M. Nawawi, and S. Pulhehe, "KONSUMSI MENUJU KONSTRUKSI MASYARAKAT KONSUMTIF," Simulacra, vol. 1, no. 2, pp. 203-211, 2018.

[5] M. C. B. Umanailo, MASYARAKAT BURU DALAM PERSPEKTIF KONTEMPORER, vol. 53, no. 9. 2015.

[6] M. C. B. Umanailo, "Consumption Diversification of Local Community," J. AGRISEP Kaji. Masal. Sos. Ekon. Pertan. dan Agribisnis, vol. 18, no. 1, pp. 61-74, Mar. 2019.

[7] M. C. B. Umanailo, "Strategi Bertahan Hidup Petani Padi Gogo di Pulau Buru," J. Ekon. Pertan. dan Agribisnis, vol. 3, no. 1, pp. 50-58, Jan. 2019.

[8] A. L. Wabula, M. Musyawir, A. Irmawati, B. Rebel, D. M. Darajat, and M. C. B. Umanailo, "Maghrib Movement," Int. J. Sci. Technol. Res., vol. 8, no. 9, pp. 2134-2138, 2019.

[9] M. C. B. Umanailo, "Postmodernisme dalam pandangan jean francois lyotard," 2018.

[10] M. C. B. Umanailo et al., "Comprehension To Village," 2018, pp. 1-2.

[11] M. C. B. Umanailo, "BUPOLO " Movement. 2019.

[12] S. Rachman, H. Hamiru, M. C. B. Umanailo, Y. Yulismayanti, and H. Harziko, "Semiotic Analysis of Indigenous Fashion in The Island of Buru," Int. J. Sci. Technol. Res., vol. 8, no. 8, pp. 1515-1519, 2019.

[13] M. C. B. Umanailo et al., "Cybercrime Case as Impact Development of Communication Technology That Troubling Society," Int. J. Sci. Technol. Res., vol. 8, no. 9, pp. 1224-1228, 2019.

[14] H. Hamiru et al., "Eucalyptus Oil Workers," Int. J. Sci. Technol. Res., vol. 8, no. 9, pp. 1817-1820, 2019.

[15] W. Malmia et al., "Problem-Based Learning as an Effort to Improve Student Learning Outcomes," Int. J. Sci. Technol. Res., vol. 8, no. 9, pp. 1140-1143, 2019.

[16] M. C. B. Umanailo, "Desa Sebagai Poros Pembangunan Daerah," 2015.

[17] M. C. B. Umanailo, M. Yulisvestra, K. K. Oki, W. Mulyasari, and R. Ridwan, "The Thought of Emile Durkheim in the Contestation of Development in Indonesia," Int. J. Sci. Technol. Res., vol. 8, no. 8, pp. 1881-1885, 2019.

[18] R. Bugis et al., "Workers in the Namlea Market," Int. J. Sci. Technol. Res., vol. 8, no. 9, pp. 2044-2047, 2019.

[19] M. C. B. Umanailo, MASYARAKAT BURU DALAM PERSPEKTIF KONTEMPORER (Kajian Kritis Perubahan Sosial di Kabupaten Buru), vol. 1. Namlea, 2017.

[20] M. C. B. Umanailo et al., "Dominance of Economic Capital in Political," in Community Development, Decentralization \& Local Autonomy Politic \& Democracy, Fisip Universitas Brawijaya, 2018, pp. 1-120.

[21] M. C. B. Umanailo, "'recycling' consumerism to construction of modern society," no. 1904, 1964.

[22] M. C. B. Umanailo, Marginalisasi Buruh Tani Akibat Alih Fungsi Lahan. 2016.

[23] M. C. B. Umanailo and T. Yatno, Kajian dan Analisis Sosiologi Dalam Bentuk Kumpulan Essay, Makalah dan Opini. 2015.

[24] M. C. B. Umanailo, I. Hamid, M. Nawawi, S. Pulhehe, S. Yusuf, and A. T. Bon, "Utilization of Qualitative Methods in Research Universities," in Proceedings of the International Conference on Industrial Engineering and Operations Management, 2019, pp. $2076-2081$.

[25] M. C. B. Umanailo, R. Umanailo, R. Bugis, and A. T. Bon, "Empowerment Community in Buru Regency," in Proceedings of the International Conference on Industrial Engineering and Operations Management, 2019, pp. 2070-2075.

[26] L. Rumkel, B. Sam, and M. C. B. Umanailo, "Village Head Partnership, Village Consultative Body and Customary Institution in Village Development," Int. J. Sci. Technol. Res., vol. 8, no. 8, pp. 1058-1063, 2019.

[27] S. S. F. Assagaf et al., "Construction of the Village as a Development Shaft in the Island Buru," Int. J. Sci. Technol. Res., vol. 8, no. 9, pp. 21392143, 2019.

[28] A. Hasan Afandi and M. C. B. Umanailo, "Watudakon Citizens 'Social Conflict on Joker Toll Road Development in 2017 in Kesamben District, Jombang Regency," J. Soc. Sci. Res., vol. Special Is, no. 5, pp. 656-661, 2018.

[29] M. C. B. Umanailo, "Keterbatasan penggunaan teknologi informasi pada pelayanan dan pembelajaran di universitas iqra buru," 2016.

[30] M. C. B. Umanailo, Sosiologi Hukum, 1st ed. Namlea: FAM PUBLISHING, 2016.

[31] B. S. Amanto, M. C. B. Umanailo, R. S. Wulandari, T. Taufik, and S. Susiati, "Local Consumption Diversification," Int. J. Sci. Technol. Res., vol. 8, no. 8, pp. 1865-1869, 2019.

[32] M. C. B. Umanailo, "EKSISTENSI WARANGGANA DALAM RITUAL TAYUB."

[33] S. Yusuf, M. C. B. Umanailo, R. N. Putri, D. Qhuril, M. Ely, and D. Darma, "Village Institution Relations in the Utilization of Village Funds in Namlea District," Int. J. Sci. Technol. Res., vol. 8, no. 8, pp. 1837-1842, 2019.

[34] M. C. B. Umanailo, N. Handayani, A. Masniati, S. H. Makatita, and S. Lisaholit, "The Urbanization and Diversification of Farmland Namlea Village," Int. J. Sci. Technol. Res., vol. 8, no. 8, pp. 1049-1053, 2019.

[35] M. C. B. Umanailo, "Overview of Phenomenological Research," 2019, pp. 1-6.

[36] M. C. B. Umanailo, "Teknik praktis grounded theory dalam penelitian kualitatif," 2018, no. April, p. 127.

[37] L. J. Buton et al., "The Effect of Nasa Liquid Organic Fertilizer Concentration and Planting Distance to Growth and Production of Beans," Int. J. Sci. Technol. Res., vol. 8, no. 9, pp. 2144-2147, 2019. 